Provided for non-commercial research and education use. Not for reproduction, distribution or commercial use.

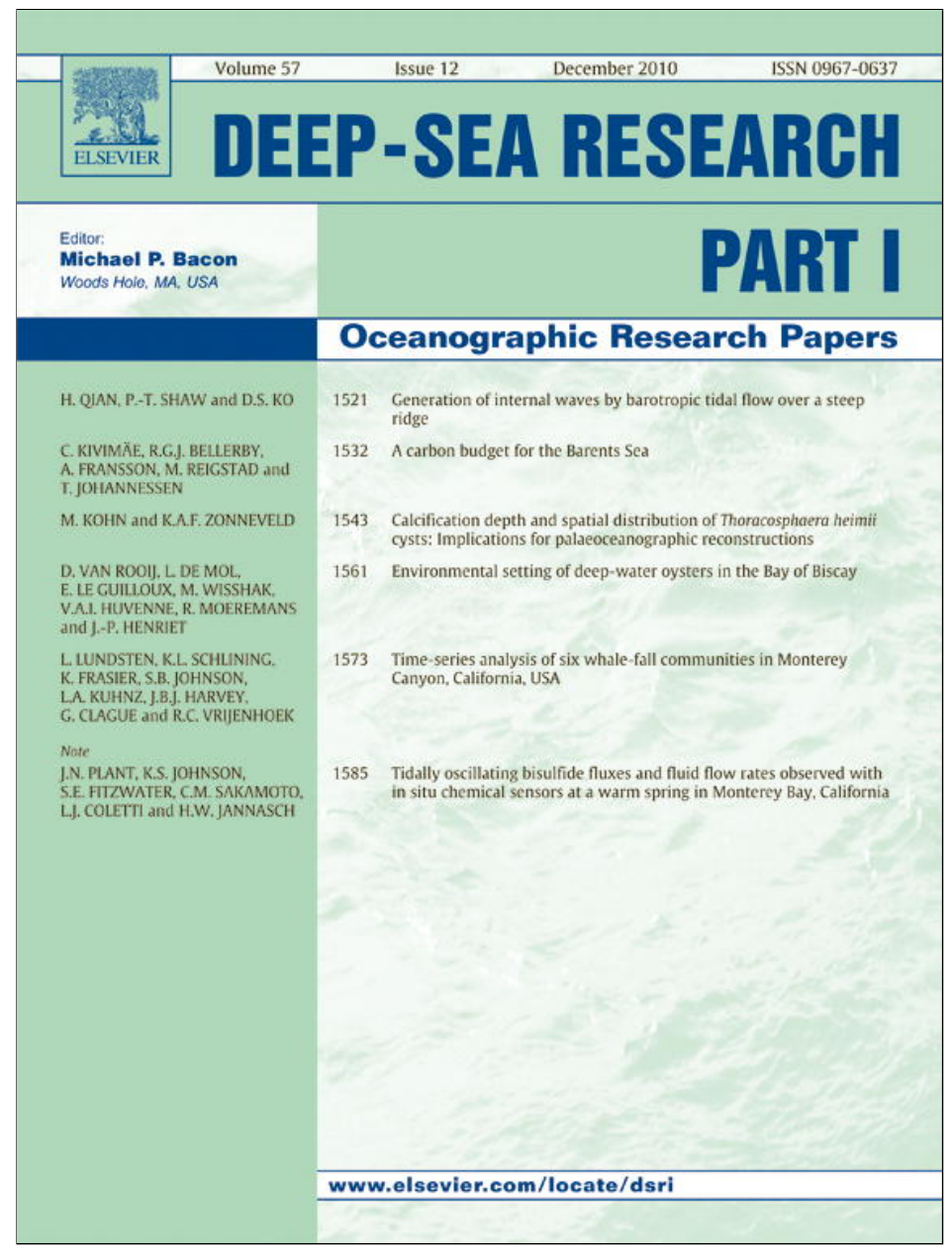

(This is a sample cover image for this issue. The actual cover is not yet available at this time.)

This article appeared in a journal published by Elsevier. The attached copy is furnished to the author for internal non-commercial research and education use, including for instruction at the authors institution and sharing with colleagues.

Other uses, including reproduction and distribution, or selling or licensing copies, or posting to personal, institutional or third party websites are prohibited.

In most cases authors are permitted to post their version of the article (e.g. in Word or Tex form) to their personal website or institutional repository. Authors requiring further information regarding Elsevier's archiving and manuscript policies are encouraged to visit:

http://www.elsevier.com/copyright 


\title{
Diet of mid-Atlantic Sowerby's beaked whales Mesoplondon bidens
}

\author{
J.N. Pereira ${ }^{\text {a,* }}$, V.C. Neves ${ }^{\text {a }}$, R. Prieto ${ }^{\text {a }}$, M.A. Silva ${ }^{\text {a,c }}$, I. Cascão ${ }^{\text {a }}$, C. Oliveira ${ }^{\text {a }}$, M.J. Cruz ${ }^{\text {a }}$, J.V. Medeiros ${ }^{\text {a }}$, \\ J.P. Barreiros ${ }^{d}$, F.M. Porteiro ${ }^{a}$, D. Clarke ${ }^{b}$ \\ ${ }^{a}$ Departamento de Oceanografia e Pescas, Centro do IMAR da Universidade dos Açores, Rua Frederico Machado no. 4, $9901-862$ Horta, Faial, Açores, Portugal \\ ${ }^{\mathrm{b}}$ Rua do Porto 18, 9930-430 São João, Pico, Açores, Portugal \\ c Biology Department, MS\#33, Woods Hole Oceanographic Institution, Woods Hole MA02543, USA \\ d Departamento de Ciências Agrárias, Universidade dos Açores and Azores Biodiversity Group, CITA-A, PT-9700-042 Angra do Heroísmo, Portugal
}

\section{A R T I C L E I N F O}

\section{Article history:}

Received 29 March 2011

Received in revised form

9 August 2011

Accepted 12 August 2011

Available online 23 August 2011

Keywords:

Azores

Sowerby's beaked whales

Strandings

Diet

Mesopelagic fish

\begin{abstract}
A B S T R A C T
The first mid-Atlantic diet of Mesoplodon beaked whales is presented, from ten Sowerby's Mesoplodon bidens stranded in the Azores region between 2002 and 2009. This doubles the worldwide number of stomachs sampled, and reveals new feeding habits for this species. The mean number of prey items per stomach was $85 \pm 89$ (range: $12-238$ ), with fish accounting for $99.3 \%$ and cephalopods contributing less than $1 \%$ of total prey. Fish otoliths from 15 families and cephalopod lower mandibles from three families were identified, representing 22 taxa. The diet consisted mainly of small mid-water fish, the most numerous being Diaphus sp., Lampanyctus sp. and Melamphaidae species. Myctophids were present in all stranded individuals, followed by Diretmidae, Melamphaidae and Opisthoproctus soleatus, while the remaining fish species were scarce or single occurrences. Consistency of diet in four different years reveals a divergence from all previous records in continental areas, where mainly neritic and shelf-break benthopelagic fish species have been reported. Mid-Atlantic Sowerby's beaked whales' showed dietary plasticity, feeding on the most abundant mid-water groups occurring between 0 and750 $\mathrm{m}$. Trophic level from prey numerical frequency was estimated at $4.4 \pm 0.46$.
\end{abstract}

(c) 2011 Elsevier Ltd. All rights reserved.

\section{Introduction}

The unveiling of beaked whales' trophic role is still in its early days, mostly due to the scarcity of available data leading to few studies published on the diet of this group. Knowledge grows at the pace of stranding events and the lack of published material is particularly evident for Mesoplodon species, for which very low numbers of prey individuals are often found per stomach (e.g. Mead et al., 1982). Fish and cephalopods are the main diet components of the 14 species of Mesoplodon (MacLeod et al., 2003), with some species relying primarily on cephalopods (e.g. M. carlhubsi and M. layardii) and others on bony fishes (e.g. M. mirus and M. bidens).

The Sowerby's beaked whale Mesoplodon bidens (Sowerby, 1804) is exclusive to the North Atlantic and is the northernmost Mesoplodon in this ocean. Distribution extends from Massachusetts (USA) to Labrador (Canada) in the west, from Iceland and Norway in the north, along the European coasts down to Madeira Islands and along the Mid-Atlantic ridge to the Azores (Macleod, 2000). The species appears to be common in some parts of its range, with higher stranding reports from the British coasts and neighboring

\footnotetext{
* Corresponding author. Tel.: +351966643842.

E-mail address: josenunopereira@uac.pt (J.N. Pereira).
}

countries (Klinowska, 1991), but there is no information on its global or regional abundance. Present knowledge on the feeding habits of Sowerby's beaked whales is limited to thirteen stomachs from stranded and by-catch individuals from North America and European coasts, revealing a primarily piscivorous whale with preference for benthopelagic species (Dix et al., 1986, Santos et al., 1994, 1995; Gannon et al., 1998; Spitz et al., 2011).

The Azores archipelago and its surrounding seamounts rise east of the Mid-Atlantic Ridge, approximately at $36-39^{\circ} \mathrm{N}$ and $25-29^{\circ} \mathrm{W}$, representing a residence or passage point for more than 25 cetacean species (Prieto and Silva, 2010). The steep topography of the region provides deep-water and slope habitats where most Mesoplodon species are commonly observed in continental areas, over the slope and beyond (e.g. Waring et al., 2001; MacLeod et al., 2004). Mesoplodon beaked whales frequent the mid-Atlantic ridge (Mar-Eco, 2004; Doksæter et al., 2008) and are common during summer in the Azores (Reiner, 1986; Leal, 2003; ICES, 2010 unpublished data), but little is known about their distribution and habitat preferences as elsewhere. There are scattered reports of Sowerby's beaked whales over slopes (Waring et al., 2001), canyons (Hooker and Baird, 1999) and deep oceanic waters (MacLeod et al., 2007).

This study provides the first insight on Sowerby's beaked whales' diet in the mid-Atlantic, based on ten specimens stranded 
in the month of July of 2002, 2004, 2005 and 2009. Dietary samples are compared between different years and with available information from other areas of its distribution. Prey choice and foraging strategy of Sowerby's beaked whales in the Azores is interpreted in light of the main preys' local abundance and habitat and current knowledge on the species.

\section{Materials and methods}

\subsection{Sample collection}

Researchers involved in the Azorean Stranding Network (RACA) carried out the necropsies and collected whole stomachs from ten Sowerby's beaked whales stranded between 2002 and
2009 (Table 1). All strandings occurred in the month of July in the central group of islands, four of which, of two and three individuals considered here as mass strandings (2002, 2005, 2009 Terceira and 2009 Faial; Table 1, Fig. 1). Stomachs were frozen and contents were subsequently sorted in the laboratory and preserved for later identification.

\subsection{Prey identification}

Full stomach samples were examined and sorted under a binocular microscope: otoliths were dry kept; all the other remains were stored in $70 \%$ ethanol. Fish otoliths and cephalopod lower beaks were identified using available keys for fish (Schmidt, 1968; Hecht and Hecht, 1981; Nolf, 1985; Smale et al., 1995;

Table 1

General information on stranded beaked whales in the Azores islands, between 2002 and 2009, with collection of stomach contents reported in this study; ${ }^{\mathrm{f}}$ indicates individuals found floating and towed to shore.

\begin{tabular}{|c|c|c|c|c|c|c|c|c|}
\hline \multirow[t]{2}{*}{ Code } & \multirow[t]{2}{*}{ Sex } & \multirow[t]{2}{*}{ Total length $(\mathrm{cm})$} & \multirow[t]{2}{*}{ Maturity $^{\mathrm{a}}$} & \multicolumn{3}{|l|}{ Stranding } & \multicolumn{2}{|c|}{ Stomach contents } \\
\hline & & & & Date & Location & Condition $^{\mathrm{b}}$ & Fish otoliths & Cephalopod beaks \\
\hline Mbi 02I & Female & 432 & M & 27 July 2002 & Pico $^{f}$ & 3 & Yes & No \\
\hline Mbi 02II & Male & $>340^{c}$ & - & 29 July 2002 & Pico & 4 & Yes & Yes \\
\hline Mbi 04I & Female & 413 & M & 19 July 2004 & Pico & 1 & Yes & Yes \\
\hline Mbi 05IA & Male & 409 & M & 21 July 2005 & Terceira & 3 & Yes & No \\
\hline Mbi 05IB & Male & 435 & M & 22 July 2005 & Terceira & 3 & Yes & No \\
\hline Mbi 09IA & Female & 388 & I & 28 July 2009 & Terceira & 1 & Yes & No \\
\hline Mbi 09IB & Male & 361 & I & 29 July 2009 & Terceira & 1 & Yes & No \\
\hline Mbi 09IIA & Female & 410 & M & 30 July 2009 & Faial & 1 & Yes & Yes \\
\hline Mbi 09IIB & Female & 414 & M & 30 July 2009 & Faial & 1 & Yes & Yes \\
\hline Mbi 09IIC & Female & 384 & I & 31 July 2009 & Faial & 1 & Yes & No \\
\hline
\end{tabular}

${ }^{a}$ Maturity established through external observation of the gonads: M-Mature; I-Immature.

b Condition: 1-Alive; 2-Freshly dead; 3-Moderately decomposed; 4-Decomposed.

${ }^{\mathrm{c}}$ Minimum length. Total length could not be measured because the individual had a fractured beak.

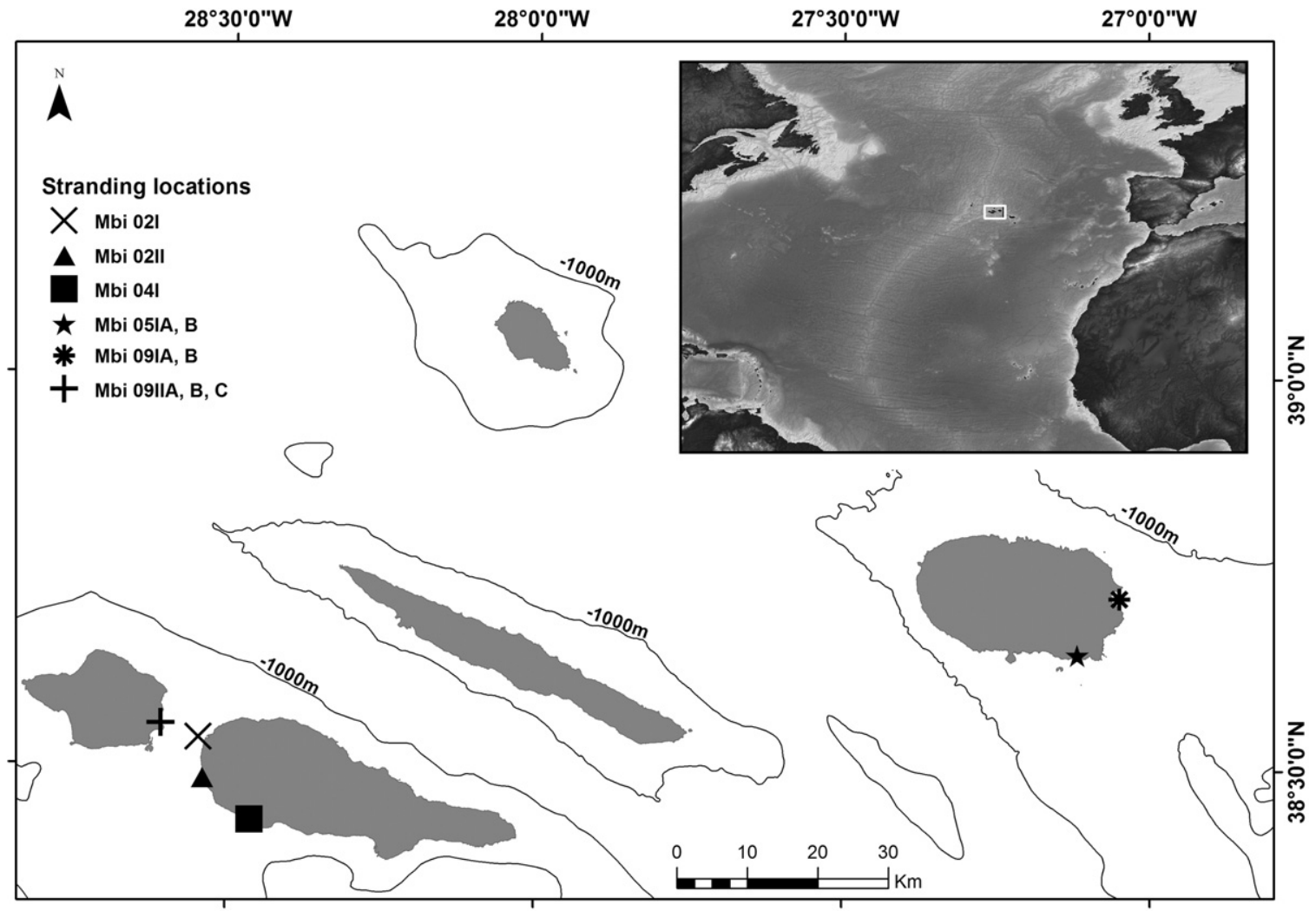

Fig. 1. Map of the Azores archipelago, with indication of stranding locations. 
Tuset et al., 2008) and for squid beaks (Clarke, 1986), and reference collections of otoliths at the University of the Azores and Malcolm Clarke's personal cephalopod beak collection. Minimum number of individual prey was estimated from remains, as total upper/lower cephalopod beaks and right/left fish otoliths.

\subsection{Data analysis}

The importance of individual prey species is shown through their frequency in number (individual numbers of each prey). Frequency of occurrence was calculated for most frequent items only (percentage of samples containing each prey type). Diet overlap was assessed using Schoener (1968) overlap index. Pair wise comparisons were made between different years (with yearly samples clustered together) and between different samples individually. Sample size prevented investigation of dietary differences associated with sex, maturity class and season. The ecology of main prey is used to infer the predators' foraging strategies in the region.

Sowerby's trophic level (TL) was estimated as follows:

$T L=1+\sum_{i=1}^{G} D C_{i} T L_{i}$

where $D C_{i}$ represents the numerical frequency of prey $(i), T L_{i}$ the trophic level of prey $(i)$, and $G$ the total number of prey. Trophic level of prey species was extracted from Cherel et al. (2009) and Froese and Pauly (2010). For items identified to genus, the regionally most abundant species were used based on the work of Sutton et al. (2008); for items identified to family, the trophic level from other species found in this study within the taxon were used.

\section{Results}

Information on the stranding events and specimens is summarized in Table 1 . The mean number of prey items per stomach was $85 \pm 89.1$ (range: $12-238$ ), with fish occurring in $100 \%$ of the stomachs and cephalopods in $30 \%$. Fish numerical frequency was 99.3\% $(N=885)$ (Table 2$)$ and cephalopods comprised less than one percent of the total number of prey items $(N=8)$ (Table 2). Fish otoliths from 15 families and cephalopod lower beaks from three families were identified, representing 22 taxa in total. Fish otoliths ranged from 22 to 235 otoliths (corresponding to 12-214 fish) per whale stomach. Cephalopods reached a maximum numerical frequency of $6.5 \%$ in a single individual (Mbi 09IIB). The high degree of erosion of the mandibles in this case suggests a long period of time since ingestion.

Fish eye lenses were present in most of the samples from 2009 namely Mbi 09IB (15), Mbi 09IIA (200-300), Mbi 09IIB (3) and Mbi 09IIC (73). Two eroded fish vertebrae and one scale were collected from Mbi 09IB. Cephalopod eye lenses were present in Mbi 09IIA (1) and Mbi 09IIB (1). Only one out of the four cephalopod beaks was considered fresh (Taonius pavo, Mbi 09IIA; Piatkowsky and Putz, 1994). No other soft tissue remains were collected and there was no record of artificial elements such as plastic or any other debris. All samples are stored and available at the Department of Oceanography and Fisheries, University of the Azores.

Table 3 summarizes information on prey indexes and ecology, including frequency of occurrence for prey with high numerical frequency. Myctophids were the most represented family, always above $30 \%$ in number, reaching $100 \%$ in stomachs with few contents. These occurred in all stranded individuals, followed by families Diretmidae and Opisthoproctidae, while the remaining fish families were represented by scarce or single occurrences. Demersal (benthopelagic) species such as Galeichtyes sp.?, Guttigadus latifrons, Gadiculus argenteus or Epigonus telescopus were rare ( $\leq 1 \% N$; Table 2 ). Main prey maximum sizes are below $15 \mathrm{~cm}$ (Froese and Pauly, 2010), and average prey size found in this study should be lower $(D$. argenteus common size around $9 \mathrm{~cm}$ ). One exception is Galeichthys sp. (probably feliceps), which is normally around $35 \mathrm{~cm}$ (Froese and Pauly, 2010).

Schoener (1968) overlap index indicated significant overlap in the diet of whales stranded in different years, with the lowest values occurring when we compare the years 2005 and 2009, possibly due to the small sample sizes (small number of contents in 2005). Individual stomach comparisons revealed significant overlap for all samples, except for the 2005 samples. Trophic level compensated for all prey items was estimated at $4.4 \pm 0.46$, a value common to most of the myctophid prey.

\section{Discussion}

All prey species and genera identified in this study are known to occur in the Azores (Santos et al., 1997), except the demersal Merluccius sp. and Galeichthys sp. The occurrence of Merluccius sp., probably M. merluccius (Linnaeus, 1758) in the region, is known from only one unpublished recent record. The species is distributed along the European coast down to Mauritania, with records extending to the Meteor seamount, south of the stranding area (Froese and Pauly, 2010). Galeichthys sp. is a more unexpected record. There are only four recognized species for this genus and only two occur in the Atlantic, more specifically on the coastal waters of SW Africa. So far, there are no valid records for this genus on the central or northeast Atlantic (Froese and Pauly, 2010). The record of Lampe (1914) of this species in the Azores waters was considered not valid by Santos et al. (1997), suggesting a possible "mislabelling of the specimens or jars".

It has been argued that stomach contents of stranded animals may not be truly representative of the feeding habits of healthy animals, revealing unusually high percentages of empty stomachs and differences in prey composition and relative abundance (Clarke, 1986; Selzer et al., 1986). None of the stomachs examined in this study were empty and our results indicate recent feeding activity in two cases. Most samples also come from mass stranding events, which reflect feeding habits more reliably than other strandings (Santos et al., 2007). Finally, the consistency of stomach contents over an 8-year period indicates this study reflects Sowerby's beaked whales' summer diet in the Azores and possibly a previous region of provenance.

The seasonal coincidence of the five stranding events, four of which are mass stranding events, gives little evidence on natural death. The pathological study of some of these strandings was still underway at the time of writing of this work and none of the possible agents could be ruled out (e.g. bio-toxins, seasonal diseases, acoustic traumas).

\subsection{Diet composition}

A restricted group of meso and bathypelagic fish formed the bulk of Sowerby's diet in the Azores from 2002 to 2009. The myctophids Diaphus sp., Lampanyctus sp., together with Opisthoproctus soleatus, Diretmus argenteus and Melamphaidae spp. (10 spp. are known in the Azores; Santos et al., 1997) are present in all years sampled (except for the small samples from 2005), representing $62 \%$ of all contents by number, with a frequency of occurrence averaging approximately $70 \%$ in all samples.

The relatively wide range of sizes among most of the prey species in this study $(3-15 \mathrm{~cm})$ makes it difficult to analyze the emphasis given by numerical frequencies to small prey in the diet (Table 3). In this sense, the numerical contribution of the two largest species should be noted, namely $D$. argenteus and 
Table 2

Numerical frequency (\% $N$ ) of the fish and cephalopod identified in the stomachs of Sowerby's beaked whales (Mesoplodon bidens) stranded in the Azores islands from 2002 to 2009; $N$ indicates minimum number of individual prey estimated from otoliths and lower beaks; family taxa organized by decreasing \% $N$ and cephalopods grouped together.

\begin{tabular}{|c|c|c|c|c|c|c|c|c|c|c|c|c|c|c|c|c|c|c|c|c|c|c|}
\hline \multirow[t]{2}{*}{ Prey list of lower taxa } & \multicolumn{2}{|c|}{$\begin{array}{l}\text { Mbi 02I } \\
27.07 .2002\end{array}$} & \multicolumn{2}{|c|}{$\begin{array}{l}\text { Mbi 02II } \\
29.07 .2002\end{array}$} & \multicolumn{2}{|c|}{$\begin{array}{l}\text { Mbi 04I } \\
19.07 .2004\end{array}$} & \multicolumn{2}{|c|}{$\begin{array}{l}\text { Mbi 05IA } \\
21.07 .2005\end{array}$} & \multicolumn{2}{|c|}{$\begin{array}{l}\text { Mbi 05IB } \\
22.07 .2005\end{array}$} & \multicolumn{2}{|c|}{$\begin{array}{l}\text { Mbi 09IA } \\
28.07 .2009\end{array}$} & \multicolumn{2}{|c|}{$\begin{array}{l}\text { Mbi 09IB } \\
29.07 .2009\end{array}$} & \multicolumn{2}{|c|}{$\begin{array}{l}\text { Mbi 09IIA } \\
30.07 .2009\end{array}$} & \multicolumn{2}{|c|}{$\begin{array}{l}\text { Mbi 09IIB } \\
30.07 .2009\end{array}$} & \multicolumn{2}{|c|}{$\begin{array}{l}\text { Mbi 09IIC } \\
31.07 .2009\end{array}$} & \multicolumn{2}{|c|}{ Totals } \\
\hline & $N$ & $\% N$ & $N$ & $\% N$ & $\mathrm{~N}$ & $\% N$ & $N$ & $\% N$ & $N$ & $\% N$ & $N$ & $\% N$ & $N$ & $\% N$ & $N$ & $\% N$ & $N$ & $\% N$ & $N$ & $\% N 1$ & $N$ & $\% N$ \\
\hline \multicolumn{23}{|l|}{ Myctophidae } \\
\hline Myctophidae spp. & & & 27 & 15.25 & & & & & & & & & & & 18 & 8.41 & 2 & 6.25 & 1 & 1.18 & 48 & 5.38 \\
\hline Diaphus sp. & 8 & 14.04 & 15 & 8.47 & 25 & 10.50 & 13 & 100.00 & 11 & 91.67 & 36 & 73.47 & 10 & 66.67 & 36 & 16.82 & 13 & 40.63 & 10 & 11.76 & 177 & 19.82 \\
\hline Electrona risso & & & & & 3 & 1.26 & & & & & 3 & 6.12 & 3 & 20.00 & 12 & 5.61 & & & & & 21 & 2.35 \\
\hline Lampanyctus sp. & 20 & 35.09 & 32 & 18.08 & 47 & 19.75 & & & & & 1 & 2.04 & & & & & & & 30 & 35.29 & 130 & 14.56 \\
\hline Bolinichthys sp.? & & & & & & & & & & & 2 & 4.08 & 1 & 6.67 & 58 & 27.10 & & & & & 61 & 6.83 \\
\hline \multicolumn{23}{|l|}{ Diretmidae } \\
\hline Diretmus argenteus & 3 & 5.26 & 14 & 7.91 & 21 & 8.82 & & & & & 3 & 6.12 & & & 3 & 1.40 & 1 & 3.13 & 1 & 1.18 & 46 & 5.15 \\
\hline Melamphaidae & & & & & & & & & & & & & & & & & & & & & & \\
\hline Melamphaidae spp. & 8 & 14.04 & 27 & 15.25 & 56 & 23.53 & & & & & & & & & 13 & 6.07 & 4 & 12.50 & 10 & 11.76 & 118 & 13.21 \\
\hline Poromitra capito & & & & & & & & & & & 2 & 4.08 & & & & & & & & & 2 & 0.22 \\
\hline Melamphaes typhlops? & & & & & & & & & & & 1 & 2.04 & & & & & & & & & 1 & 0.11 \\
\hline Opisthoproctidae & & & & & & & & & & & & & & & & & & & & & & \\
\hline O. soleatus & 1 & 1.75 & 15 & 8.47 & 8 & 3.36 & & & & & & & & & 44 & 20.56 & 6 & 18.75 & 14 & 16.47 & 88 & 9.85 \\
\hline Ariidae & & & & & & & & & & & & & & & & & & & & & & \\
\hline Galeichthys sp.? & & & 3 & 1.69 & 6 & 2.52 & & & & & & & & & & & & & & & 9 & 1.01 \\
\hline Microstomatidae & & & & & & & & & & & & & & & & & & & & & & \\
\hline Nansenia sp.? & & & & & & & & & & & & & & & 2 & 0.93 & & & 6 & 7.06 & 8 & 0.90 \\
\hline Scopelarchidae & & & & & & & & & & & & & & & & & & & & & & \\
\hline Scopelarchus sp. & 3 & 5.26 & & & & & & & & & & & & & & & & & & & 3 & 0.34 \\
\hline Gadidae & & & & & & & & & & & & & & & & & & & & & & \\
\hline Gadiculus argenteus & & & & & 1 & 0.42 & & & & & & & & & & & & & 1 & 1.18 & 2 & 0.22 \\
\hline Melanonidae & & & & & & & & & & & & & & & & & & & & & & \\
\hline Melanonus zugmayeri & & & & & 2 & 0.84 & & & & & & & & & & & & & & & 2 & 0.22 \\
\hline Epigonidae & & & & & & & & & & & & & & & & & & & & & & \\
\hline Epigonus telescopus & & & & & & & & & & & & & & & & & & & 1 & 1.18 & 1 & 0.11 \\
\hline Gonostomatidae & & & & & & & & & & & & & & & & & & & & & & \\
\hline Gonostoma denudatum & & & & & & & & & & & & & & & & & & & 1 & 1.18 & 1 & 0.11 \\
\hline Moridae & & & & & & & & & & & & & & & & & & & & & & \\
\hline Guttigadus latifrons & & & & & 1 & 0.42 & & & & & & & & & & & & & & & 1 & 0.11 \\
\hline Macrouridae & & & & & & & & & & & & & & & & & & & & & & \\
\hline $\begin{array}{l}\text { Odontomacrurus } \\
\text { murrayi }\end{array}$ & & & & & & & & & & & & & & & 1 & 0.47 & & & & & 1 & 0.11 \\
\hline Merlucciidae & & & & & & & & & & & & & & & & & & & & & & \\
\hline Merluccius sp. & & & & & 1 & 0.42 & & & & & & & & & & & & & & & 1 & 0.11 \\
\hline Paralepididae & & & & & & & & & & & & & & & & & & & & & & \\
\hline Paralepis sp. & & & & & 1 & 0.42 & & & & & & & & & & & & & & & 1 & 0.11 \\
\hline Cranchiidae & & & & & & & & & & & & & & & & & & & & & & \\
\hline Taonius pavo & & & & & & & & & & & & & & & 1 & 0.47 & & & & & 1 & 0.11 \\
\hline Cycloteuthidae & & & & & & & & & & & & & & & & & & & & & & \\
\hline Discoteuthis laciniosa & & & 1 & 0.56 & & & & & & & & & & & & & & & & & 1 & 0.11 \\
\hline Histioteuthidae & & & & & & & & & & & & & & & & & & & & & & \\
\hline H. meleagroteuthis & & & & & & & & & & & & & & & 1 & 0.47 & 1 & 3.13 & & & 2 & 0.22 \\
\hline Unidentified cephs & & & 1 & 0.56 & 2 & 0.84 & & & & & & & & & & & 2 & 6.25 & & & 5 & 0.56 \\
\hline Unidentified fish & 14 & 24.56 & 43 & 24.29 & 64 & 26.89 & & & 1 & 8.33 & 1 & 2.04 & 1 & 6.67 & 25 & 11.68 & 3 & 9.38 & 10 & 11.76 & 162 & 18.84 \\
\hline Total & 57 & - & 177 & - & 238 & - & 13 & - & 12 & - & 49 & - & 15 & - & 214 & - & 31 & - & 85 & - & 893 & 100 \\
\hline
\end{tabular}

Galeichthys sp., which average $27 \mathrm{~cm}$ and $55 \mathrm{~cm}$, respectively. Prey size or weight estimations based on mesopelagic fish otoliths were not possible, due to the lack of biometric regression equations. This information seems absent from current literature, and it is of major relevance as it assists further analysis of these results, such as for biomass estimates. Nevertheless, prey preference studies based on numerical occurrence is a useful approach when combined with in situ abundances as developed below (e.g. Hansson, 1998).

\subsection{Feeding activity and prey ecology}

The meso and bathypelagic fish communities just north of the stranding area were described during one of the stranding periods (27 June to 01 July $2004 ; 42.81-41.24^{\circ} \mathrm{N}$; Sutton et al., 2008). A large vertical migrating mesopelagic fish assemblage occupies the upper 0-750 m, termed the "Lanternfish group". Characterized by high diversity and low abundance, compared with the more productive areas to the north of the Mid-Atlantic Ridge, it is dominated by the Myctophidae family (29 spp., $50.8 \% N, 26.9 \%$ in biomass; Sutton et al., 2008).

Myctophids represent $49 \%$ by number of the Sowerby's beaked whale diet in this study. The most important prey, Diaphus sp. and Lampanyctus sp., are amongst the most abundant species in the Azores region, ranking in the top 10 at these depths (Sutton et al., 2008). It seems relevant to note they account for $34 \%$ in our study while reaching only $5.6 \%$ in net surveys. This could indicate possible prey or habitat preference, once Diaphus spp. may be preferentially associated to bottom structures (F.M. Porteiro personal communication).

Between 750 and $1500 \mathrm{~m}$ there is a decrease in abundance and increase in biomass, with two discrete deep-meso/upper-bathypelagic assemblages, both co-dominated by Cyclothone microdon: one with three large melamphaid species and the second 
Table 3

Most frequent prey items with indication of frequency in number (\% $N)$, frequency of occurrence (\%O), number of possible species (spp.), Adult Max Lengths of all possible species in the region (AML, cm; source: www.fishbase.org) and vertical migration (M) and non-migration (NM).

\begin{tabular}{|c|c|c|c|c|c|c|c|c|c|c|c|}
\hline Family & Lower taxon & $N$ & $\% N$ & $\% O$ & 2002 & 2004 & 2005 & 2009 & spp. & AML & Migrate \\
\hline Myctophidae & Diaphus sp. & 177 & 19.8 & 100 & $x$ & $\mathrm{x}$ & $\mathbf{x}$ & $\mathbf{x}$ & 7 & $6-15$ & $\mathbf{M}$ \\
\hline Myctophidae & Lampanyctus sp. & 130 & 14.6 & 50 & $\mathrm{x}$ & $\mathrm{x}$ & & $\mathbf{x}$ & 2 & $8.5-13.8$ & $\mathbf{M}$ \\
\hline Melamphaidae & Melamphaidae spp. & 118 & 13.2 & 60 & $x$ & $\mathrm{x}$ & & $\mathrm{x}$ & 10 & $2.9-13.1$ & $\mathbf{M}$ and $\mathrm{NM}$ \\
\hline Opistoproctidae & O. soleatus & 88 & 9.9 & 60 & $\mathrm{x}$ & $\mathrm{x}$ & & $\mathbf{x}$ & 1 & 10.5 & NM \\
\hline Myctophidae & Bolinicthys sp.? & 61 & 6.8 & 30 & & & & $\mathbf{x}$ & 4 & $4.5-15.3$ & м \\
\hline Myctophidae & Myctophidae spp. & 48 & 5.4 & 40 & & & & $\mathrm{x}$ & 25 & $2.9-14.3$ & $\mathbf{M}$ \\
\hline Diretmidae & Diretmus argenteus & 46 & 5.2 & 70 & $\mathrm{x}$ & $\mathrm{x}$ & & $\mathrm{x}$ & 1 & 27.6 & NM \\
\hline Myctophidae & Electrona risso & 21 & 2.4 & 40 & & $\mathrm{x}$ & & $x$ & 1 & 8.2 & M \\
\hline Ariidae & Galeichthys sp.? & 9 & 1.0 & 20 & $\mathbf{x}$ & $\mathrm{x}$ & & & 1 & 55 & NM \\
\hline- & Cephalopods (all) & 9 & 1.0 & 40 & $\mathrm{x}$ & $\mathrm{x}$ & & $\mathbf{x}$ & $3^{b}$ & - & $\mathbf{M}$ and $\mathrm{NM}$ \\
\hline - & Fish spp. $(<1 \% N)^{\mathrm{a}}$ & 24 & 2.7 & - & $\mathrm{x}$ & $x$ & & $\mathbf{x}$ & - & - & - \\
\hline \multirow[t]{2}{*}{ - } & Non identified fish & 162 & 18.1 & 90 & $\mathrm{x}$ & $\mathrm{x}$ & $\mathbf{x}$ & $\mathrm{x}$ & - & - & - \\
\hline & Total & 893 & $100 \%$ & & & & & & & & \\
\hline
\end{tabular}

${ }^{a}$ Includes 12 different species.

b Three unidentified items not included.



Fig. 2. Frequency in number $(\% N)$ of main prey, predator foraging depths (from M. densirostris off Canary Islands, Tyack et al., 2009; max depth given by Baird et al., 2008) and night-time distribution for vertical migrating prey: main depths for 0 . soleatus and $D$. argenteus (non migrators); Myctophidae (25 spp.) average values for night-time maximum depths are given; Melamphaidae (10 spp.) wide distribution depths not represented (source: Fishbase (Froese and Pauly, 2010)).

with the myctophid Benthosema glaciale (Sutton et al., 2008). Considering the numerical importance of the Melamphaidae species in our study, Sowerby's beaked whale foraging depths likely extends beyond $750 \mathrm{~m}$, where this group of species becomes more abundant, though these could be also benefiting from night-time vertical ascension not contemplated on Sutton et al. (2008). According to Sutton et al. (2008) D. argenteus and one melamphaid (S. mizolepis) have important biomass contributions both in the upper and lower community, whereas the absence of $C$. microdon in any of our samples may indicate prey selectivity.

Main prey in the mid-Atlantic Azores region migrate to shallower depths at night aggregating in horizontal layers, becoming shallower than the maximum foraging depths (Baird et al., 2008; Tyack et al., 2009; Fig. 2). Diel patterns of vertical movements have been reported for several odontocetes, reflecting shifts in prey vertical availability (Benoit-Bird and Au, 2003) or predator avoidance (Baird et al., 2008). Recent studies on Mesoplodon densirostris off Hawaii revealed similar diving rates during day and night, leading Baird et al. (2008) to postulate that either prey do not exhibit diel vertical migrations, or that the whales switch prey species at night. Considering the importance of mesopelagic prey for $M$. bidens in this study, shallower foraging depths should occur during night-time.

\subsection{Sowerby's beaked whale diet}

Sowerby's beaked whales in the Azores are primarily fish eaters, as in other regions of its range (MacLeod et al., 2003; Spitz et al., 2011). Diet in the Azores contrasts to the mostly benthopelagic prey records from the few studies conducted elsewhere. Dix et al. (1986) reported a single Gadidae spp. from a stranded male in Newfoundland, on one of the first western Atlantic records. From Scotland, Santos et al. (1994, 1995) (see also MacLeod et al., 2003) reported 3 specimens, totaling 17 items, with Merluccidae spp. (52.9\%) and Gadidae spp. (41.3\%) being the most frequent prey. Gannon et al. (1998) reported on six freshly killed Sowerby's in the NE Atlantic, but 4106 food items were referred only asbottom-dwelling deep-water fish (deeper than $400 \mathrm{~m}$ ) between 10 and $20 \mathrm{~cm}$ length. From the Bay of Biscay Siptz et al. (2011) reported three Sowerby's containing four Gadidae species $(51.6 \% N)$, one $M$. merluccius and one Myctophidae, together with Sepia sp. and several swimming crab Polybius spp. (33\%M).

According to these reports, Sowerby's near continental areas forage for neritic benthopelagic prey, probably in the lower shelf and shelf-break where these prey commonly occur (e.g., Mahon and Smith, 1989; Cartes et al., 2009). In the Azores, Sowerby's are feeding mostly on mid-water numerically abundant prey. Their advection through lateral currents and vertical entrapment over seamounts and island slopes are a long considered phenomena (Isaacs and Schwartzlose, 1965; Koslow, 1997), and foraging does occur near the bottom were these prey might also became available (Porteiro and Sutton, 2007). Many bottom dwelling fish reported as prey in other areas, such as Merluccidae spp. (Gannon et al., 1998) and Gadidae spp. (e.g. Spitz et al., 2011), achieve larger sizes than the main prey here reported, except for some of the scarce demersal and benthopelagics from this study. Sowerby's depredation on longline fishing gear has been recently suggested (Spitz et al., 2011), and although an artisanal bottom longline fishery extracts about 6000 tons per year of demersal fish species in this area (INE, 2009), mostly between 200 and $600 \mathrm{~m}$ 
depth (Morato et al., 2001), no prey with commercial value was found in our study, and there are no records of interactions of these whales with the Azorean bottom fisheries. The geomorphology of this insular and mid-Atlantic region and/or the actual scarcity of gadids and merluccids should provide explanatory variables for the regional differences in the feeding ecology. The regional prevalence of mid-water prey reveals dietary plasticity, which has been proposed by MacLeod et al. (2003) for all beaked whales, and is here revealed for Sowerby's beaked whales for the first time. Population level responses are expected when predators become subject to geographic variations in prey resources (e.g. Rutz and Bijlsma, 2006), and this should be taken into consideration in future population assessments.

There is as few data on Sowerby's diet as in its trophic level (TL). Early estimates by Ostrom et al. (1993) pointed to a TL of 3.7 based on stable isotope ratios (data corrected considering herbivores $\mathrm{TL}=2$ following Pauly and Christensen, 1995). Pauly et al. (1998) calculated a 4.3 level for M. bidens, weighting grouped prey items from scarce existing records. Even though cephalopods were estimated to contribute $50 \%$, which is not supported by any record to our knowledge, their values were very close to our estimate. The trophic level of 4.4 in this study reflects the predominance of myctophids and melamphaids and higher values are expected for other regions where larger species are being taken.

\section{Acknowledgments}

The authors sincerely acknowledge everyone involved in the efforts of recuperation and data collection during the stranding events. We thank Dr. Malcolm Clarke for aid in the identification phase, and three anonymous reviewers for valuable comments on the original manuscript.

VN and M.A.S. were supported by FCT postdoctoral Grants (SFRH/BPD/26657/2006 and SFRH/BPD/29841/2006, respectively) and R.P., I.C. and C.O. were supported by FCT doctoral Grants (SFRH/BD/32520/2006, SFRH/BD/41192/2007 and SFRH/BD/ $37668 / 2007$, respectively). This work was partly financed by FEDER funds, through the Competitiveness Factors Operational Programme - COMPETE, and by national funds, through FCT Foundation for Science and Technology, under project PTDC/MAR/ 74071/2006. IMAR-DOP/UAç is the R\&D Unit \#531 and part of the Associated Laboratory ISR funded through the Pluri-annual and Programmatic funding schemes of FCT-MCTES and DRCT-Azores. This research was conducted under license of the Environment Directorate of the Regional Government of the Azores.

\section{References}

Baird, R.W., Webster, D.L., Schorr, G.S., McSweeney, D.J., Barlow, J., 2008. Diel variation in beaked whale diving behavior. Mar. Mamm. Sci. 24 (3), 630-642. Benoit-Bird, K.J., Au, W.W.L., 2003. Prey dynamics affect foraging by a pelagic predator (Stenella longirostris) over a range of spatial and temporal scales. Behav. Ecol. Sociobiol. 53, 364-373.

Cartes, J.E., Hidalgo, M., Papiol, V., Massutí, E., Moranta, J., 2009. Changes in the diet and feeding of the hake Merluccius merluccius at the shelf-break of the Balearic Islands: influence of the mesopelagic-boundary community. Deep Sea Res. Part I: Oceanogr. Res. Pap. 56 (3), 344-365.

Cherel, Y., Ridoux, V., Spitz, J., Richard, P., 2009. Stable isotopes document the trophic structure of a deep-sea cephalopod assemblage including giant octopod and giant squid. Biol. Lett. 5, 364-367.

Clarke, M.R., 1986. A Handbook for the Identification of Cephalopod Beaks. Clarendon, Oxford, GB (273 pp.).

Dix, L., Lien, J., Sergeant, D.E., 1986. A North Sea beaked whale Mesoplodon bidens in Conception Bay, Newfoundland, Canada. Can. Field Nat. 100, 389-391.

Doksæter, L., Olsenb., E., Nøttestadb, L., Ferno, A., 2008. Distribution and feeding ecology of dolphins along the Mid-Atlantic Ridge between Iceland and the Azores. Deep-Sea Res. II 55, 243-253.
Froese, R., Pauly, D. (Eds.), 2010. FishBase. World Wide Web Electronic Publication. $\langle$ www.fishbase.org $\rangle$, version (09/2010)

Gannon, D.P. Craddock, J.E., Read, A.J., 1998. Food habits of beaked whales (Mesoplodon bidens and Ziphius cavirostris) from the northeastern US. In: Proceedings of the Abstracts of the World Marine Mammal Science Conference. Monaco, 20-24th January 1998, p. 49.

Hansson, S., 1998. Comment on review by Cortés, E., 1997. Can. J. Fish. Aquat. Sci. 54, 726-738 (Can. J. Fish. Aquat. Sci. 55, 2706-2707).

Hecht, T., Hecht, A., 1981. A descriptive systematic study of the otoliths of the neopterygean marine fishes of South Africa Part IV Siluriformes and Myctophiformes. Trans. R. Soc. S. Afr. 44 (3), 401-440.

Hooker, S.K., Baird, R.W., 1999. Observations of Sowerby's Beaked Whales, Mesoplodon bidens, in the Gully, Nova Scotia. Can. Field-Nat. 113 (2), 273-277.

ICES, 2010. Report of the Working Group on Marine Mammal Ecology (WGMME). ICES CM 2010/ACOM:24. Horta, The Azores, 12-15 April 2010, 212 pp.

INE, 2009. Estatísticas da Pesca 2009 (Fisheries statistics 2009). I.P., Lisboa, Portugal, 2010

Isaacs, J.D., Schwartzlose, R.A., 1965. Migrant sound scatterers: Interaction with the seafloor. Science 150, 1810-1813.

Klinowska, M., 1991. Dolphins, Porpoises and Whales of the World-The IUCN Red Data Book. IUCN, Cambridge (pp. 277-281).

Koslow, J.A., 1997. Seamounts and the ecology of Deep-Sea fisheries. Am. Sci. 85, 168-176.

Leal, M.J.R., 2003. Estudo dos padrões de ocorrência de baleias de bico na costa sul do pico, Açores. B.Sc. Thesis. Faculty of Marine and Environmental Sciences, University of the Algarve, $51 \mathrm{pp}$.

Macleod, C.D., 2000. Review of the distribution of Mesoplodon species (order Cetacea, family Ziphiidae) in the North Atlantic. Mamm. Rev. 30, 1-8.

MacLeod, C.D., Santos, M.B., Pierce, G.J., 2003. Review of data on diets of beaked whales: evidence of niche separation and geographic segregation. J. Mar. Biol. Assoc. UK 83, 651-665.

MacLeod, C.D., Hauser, N., Peckham, H., 2004. Diversity, abundance and structure of the cetacean community on summer months east of Great Abaco, Bahamas. J. Mar. Biol. Assoc. UK 84, 469-474.

MacLeod, C.D., Weir, C.R., Pierpoint, C., Harland, E.J., 2007. The habitat preferences of marine mammals west of Scotland (UK). J. Mar. Biol. Assoc. 87, 157-164.

Mahon, R., Smith, R.W., 1989. Demersal fish assemblages on the Scotian Shelf, Northwest Atlantic: spatial distribution and persistence. Can J. Fish. Aquat. Sci. 46 (Suppl. 1), 134-152.

Mar-Eco, 2004. Mar-Eco Cruise to the Mid-Atlantic Ridge, Iceland-Azores. Cruise Report-RVGO. Sars. Toktrapport, Havforskningsinstituttet Nr. 19.

Morato, T., Guénette, S., Pitcher, T., 2001. Fisheries of the Azores, 1982-1999. In: Zeller, D., Watso, R, Pitcher, T, Pauly, D. (Eds.), Fisheries impacts on North Atlantic Ecosystems: Catch, Effort and National/Regional Data Sets. Fisheries Centre Research Reports, vol. 9(3). University of British Columbia, pp. $214-220$

Mead, J.G., Walker, W.A., Houck, W.J., 1982. Biological observation on Mesoplodon carlhubbsi (Cetacea: Ziphiidae). Smithson. Contrib. Zool. 344, 1-25.

Nolf, D., 1985. Otolithi piscium. In: Schultze, H.P. (Ed.), Handbook of Paleoichthyology, vol. 10. Gustav Fisher Verlag, Stuttgart.

Ostrom, P.H., Lien, J., Macko, S.A., 1993. Evaluation of the diet of Sowerby's beaked whale, Mesoplodon bidens, based on isotopic comparisons among northwestern Atlantic cetaceans. Can. J. Zool. 71 (4), 858-861.

Pauly, D., Christensen, V., 1995. Primary production required to sustain global fisheries. Nature 374, 255-257.

Pauly, D., Trites, A.W., Capuli, E., Christensen, V., 1998. Diet composition and trophic levels of marine mammals. ICES J. Mar. Sci. 55, 467-481.

Piatkowsky, U., Putz, K., 1994. Squid diet of Emperor penguins (Aptenodytes forsteri) in the eastern Weddell Sea, Antartica during late summer. Antart. Sci. 6 (2), 241-247.

Porteiro, F.M., Sutton, T., 2007. Midwater fish assemblages and seamounts. In: Pitcher, T.J., Morato, T., Hart, P.J.B., Clark, M.R., Haggan, N., Santos, R.S. (Eds.), Seamounts: Ecology, Fisheries and Conservation Blackwell, Oxford, pp. 101-116.

Prieto, R., Silva, M.A., 2010. Marine mammals. In: Borges, P.A.V., Costa, A., Cunha, R., Gabriel, R., Gonçalves, V., Martins, A.F., Melo, I., Parente, M., Raposeiro, P., Rodrigues, P., Santos, R.S., Silva, L., Vieira, P., Vieira, V. (Eds.), A List of the Terrestrial and Marine Biota from the Azores Princípia, Cascais (pp. 344-345, 432 pp.).

Reiner, F., 1986. First Record of Sowerby's beaked whale from Azores. The Scientific Reports of Whale Research Institute, vol. 37, pp. 103-107.

Rutz, C., Bijlsma., R., 2006. Food-limitation in a generalist predator. Proc. R. Soc. B 273, 2069-2076.

Santos, M.B., Pierce, G.J., Ross, H.M., Reid, R.J., Wilson, B., 1994. Diets of small cetaceans from the Scottish coast. International Council for the Exploration of the Sea. Marine Mammal Committee. C.M. 1994/N:11.

Santos, M.B., Pierce, G.J., Wijnsma, G., Ross, H.M., Reid, R.J., 1995. Diets of small cetaceans stranded in Scotland 1993-1995. International Council for the Exploration of the Sea. Marine Mammal Committee. C.M. 1995/N:6.

Santos, M.B., Martin, V., Rabelo, M., Fernandez, A., Pierce, G.J., 2007. Insights into the diet of beaked whales from the atypical mass stranding in the Canary Islands in September 2002. J. Mar. Biol. Assoc. UK 87 (01), 243-251.

Santos, R.S., Porteiro, F.M., Barreiros, J.P., 1997. Marine fishes of the Azores: annotated checklist and bibliography. Bull. Univ. Azores (Suppl. 1), 244. 
Selzer, L.A., Early, G., Fiorelli, P.M., Payne, P.M., Prescott, R., 1986. Stranded animals as indicators of prey utilization by harbor seals, Phoca vitulina concolor, in southern New England. Fish. Bull. (Natl. Oceanic Washington, DC) 84, 217-220. Schmidt, W., 1968. Vergleichend morphologische Studie uber die Otolithchen mariner Knochenfische. Arch. Fisscheneiwiies, Berlin, 1-70 (19 1.1-96).

Schoener, T.W., 1968. The Anolis lizards of Bimini: resource partitioning in a complex fauna. Ecology 49, 704-726.

Smale, M.J., Watson, G., Hecht, T., 1995. Otolith atlas of southern African marine fishes. J.L.B. Smith Institute of Ichthyology (Grahamstown, South Africa), Grahamstown, S.A., vol. 1.

Spitz, J., Cherel, Y., Bertin, S., Kiszka, J., Dewez, A., Ridoux, V., 2011. Prey preferences among the community of deep-diving odontocetes from the Bay of Biscay, Northeast Atlantic. Deep-Sea Res. I 58, 273-282.
Sutton, T.T., Porteiro, F.M., Heino, M., Byrkjedal, I., Langhelle, G., Anderson, C.I.H., Horne, J., Søiland, H., Falkenhaug, T., Godø, O.R., Bergstad, O.A., 2008. Vertical structure, biomass and topographic association of deep-pelagic fishes in relation to a mid-ocean ridge system. Deep-Sea Res. II 55 , $161-184$.

Tuset, V.M., Lombarte, A., Assis, C.A., 2008. Otolith Atlas for the western Mediterranean, north and central eastern Atlantic. Sci. Mar. 72S1, 7-198.

Tyack, P.L., Johnson, M., Soto, N.A., Sturlese, A., Madsen, P.T., 2009. Extreme diving of beaked whales. J. Exp. Biol. 209, 4238-4253.

Waring, G.T., Hamazaki, T., Sheehan, D., Wood, G., Bake, S., 2001. Characterization of beaked whale (Ziphiidae) and sperm whale (Physeter macrocephalus) summer habitat in shelf-edge and deeper waters off the Northeast US. Mar. Mamm. Sci. 17 (4), 703-717. 